\title{
Natural Plant Protection by 2,4-Diacetylphloroglucinol- Producing Pseudomonas spp. in Take-All Decline Soils
}

\author{
Jos M. Raaijmakers and David M. Weller \\ USDA-Agricultural Research Service, 367 Johnson Hall, Washington State University, Pullman 99164-6430, \\ U.S.A. \\ Accepted 6 November 1997.
}

\begin{abstract}
Take-all decline (TAD) is a natural biological control of the wheat root disease "take-all" that develops in response to the disease during extended monoculture of wheat. The research to date on TAD has been mostly descriptive and no particular occurrence is yet fully understood. We demonstrate that root-associated fluorescent Pseudomonas spp. producing the antibiotic 2,4-diacetylphloroglucinol (Phl) are key components of the natural biological control that operates in TAD soils in Washington State (U.S.A.). Phlproducing Pseudomonas spp. were present on roots of wheat grown in TAD soils at or above the threshold population density required for significant suppression of take-all of wheat. The specific suppression that operates in TAD soils was lost when Phl-producing fluorescent Pseudomonas spp. were eliminated, and conducive soils gained suppressiveness to take-all when Phl-producing Pseudomonas strains were introduced via mixing in small amounts of TAD soil. Introduction of selected Phlproducing strains into take-all conducive soils provided control of take-all of wheat to a level similar to that obtained in the complementary TAD soils.
\end{abstract}

Soilborne plant pathogens are major yield-limiting factors in the production of food and fiber crops and ornamentals. Because genetic resistance in plants to many soilborne pathogens is rare, agriculture depends on other practices such as soil fumigation and crop rotation to control these diseases. Our studies have focused on take-all, caused by the fungus Gaeumannomyces graminis var. tritici, which is one of the most important root diseases of wheat worldwide (Asher and Shipton 1981). Although wheat is particularly susceptible to the take-all fungus, various other Gramineae, like barley, rye, and triticale, can also be infected (Gutteridge et al. 1993). Traditionally, take-all has been controlled by a combination of crop rotation and tillage, practices that reduce the inoculum potential of the pathogen. However, because long rotations are often not economically feasible, and tillage contributes to soil erosion, the current trend in cereal production is toward less till-

Corresponding author: Jos M. Raaijmakers;

E-mail: jos.raaijmakers@medew.fyto.wau.nl

This article is in the public domain and not copyrightable. It may be freely reprinted with customary crediting of the source. The American Phytopathological Society, 1998. age and two or three consecutive wheat crops before a break. Both of these practices exacerbate take-all. The only known source of genetic resistance to take-all is in the distant wild relative of wheat Dasapyrum villosum (formerly Haynaldia villosa) (Foex 1935; Linde-Laursen et al. 1973). However, breeding wheat for resistance to the take-all fungus has been unsuccessful, and methods of chemical control are limited. The need for agriculture to become more sustainable and less dependent on chemical pesticides has necessitated the development of alternative approaches to control take-all and other diseases caused by soilborne pathogens.

Take-all decline (TAD) is a natural biological control of take-all and is defined as a spontaneous reduction in disease and increase in yield with extended monoculture of wheat or barley (Slope and Cox 1964). TAD was first observed more than 50 years ago (Fellows and Ficke 1934; Glynne 1935) and is now recognized as a worldwide phenomenon (Hornby 1983). The similarity of TAD throughout the world is remarkable in view of the broad range of soil types, climates, and agronomic conditions under which wheat is cultivated. Field studies have clearly indicated that the development of TAD follows a consistent pattern everywhere, apparently requiring the continuous cultivation of wheat and the presence of the take-all fungus. Factors such as soil type and previous cropping history seem only to modulate the extent and speed of development of TAD (Shipton 1975). Despite the fact that the incidence and severity of take-all eventually decline, most growers abandon monoculture prematurely because interim losses can be considerable. Once established, however, TAD permits a recovery in yield of wheat and it persists as long as monoculture continues. Understanding the fundamental mechanism(s) of TAD could lead to an effective biological control of take-all. However, the research to date has been mostly descriptive and no particular occurrence of TAD is yet fully understood.

One widely held explanation for TAD is based on microbiological interactions between the take-all pathogen and specific, root-associated microorganisms (Cook and Rovira 1976; Rovira and Wildermuth 1981). Although many genera of microorganisms have been implicated in TAD, the fluorescent Pseudomonas spp. have received much attention (Cook et al. 1995). Wheat roots from TAD soils supported significantly larger populations of fluorescent Pseudomonas spp. inhibitory to the take-all fungus than roots from take-all-conducive soils (Weller et al. 1988), and Pseudomonas strains from TAD soils were significantly more effective at controlling take-all than 
those from conducive soils (Weller et al. 1985). Various strains from TAD soils produced the antibiotic 2,4-diacetylphloroglucinol (Phl) (Keel et al. 1996) and some produced phenazine antibiotics (Thomashow and Weller 1988). Both $\mathrm{Phl}$ and phenazines are antibiotics with antibacterial and antifungal properties, and are key determinants of take-all suppression by some Pseudomonas strains (Thomashow and Weller 1988; Keel et al. 1992). Recently, we demonstrated that Phl-producing fluorescent Pseudomonas spp. were present on roots of wheat grown in three different TAD soils from Washington State at relatively high densities, whereas phenazine-producing Pseudomonas spp. were not detected in any of the soils tested (Raaijmakers et al. 1997). Collectively, these results led to the hypothesis that Phl-producing fluorescent Pseudomonas spp. play a key role in TAD soils in Washington State. In this study, we provide more conclusive evidence that Phl-producing fluorescent Pseudomonas spp. are key components of the specific suppression that operates in TAD soils in Washington.

\section{RESULTS}

\section{Population dynamics of indigenous Phl-producing fluorescent Pseudomonas spp.}

Wheat plants were grown in the Quincy TAD and Quincy virgin soils for nine successive cycles of 4 weeks each. This

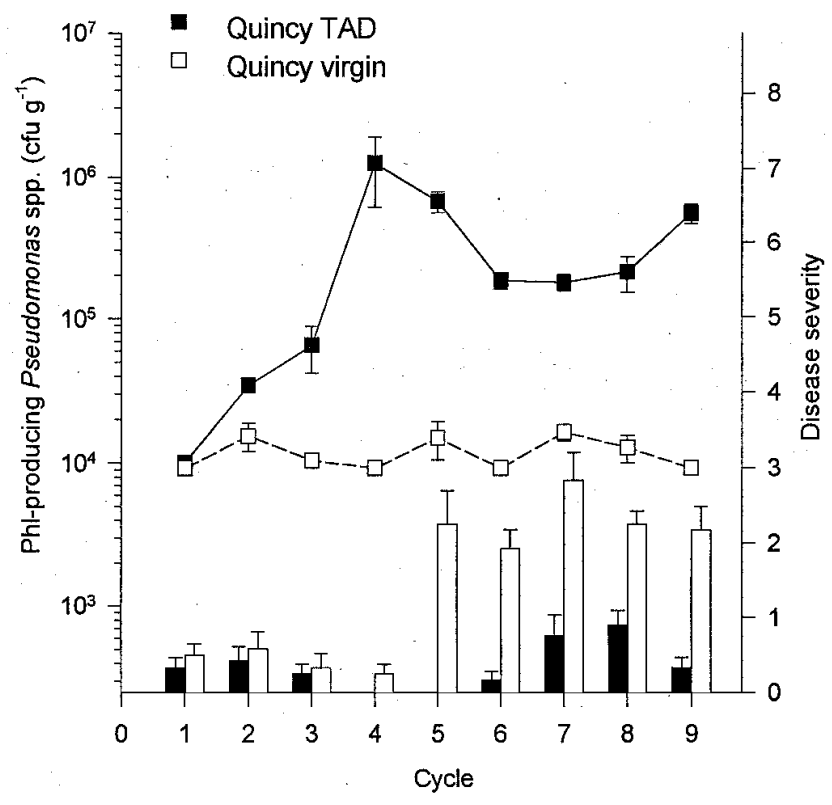

Fig. 1. Population dynamics of naturally occurring, 2,4-diacetylphloroglucinol (Phl)-producing fluorescent Pseudomonas spp. and severity of take-all disease on roots of wheat grown in Quincy virgin and in Quincy take-all decline (TAD) soil under controlled conditions for nine successive cycles of 4 weeks each. Severity of take-all is presented as bars and was rated on a 0 to 8 scale $(0=$ no disease, and $8=$ dead plant $)$. Rhizosphere population density of Phl-producing fluorescent Pseudomonas spp. is presented as lines and was determined by colony hybridization with a specific probe followed by the polymerase chain reaction with specific primers. For each cycle, mean values and standard errors are presented. Phl-producing Pseudomonas spp. were not detected on roots of wheat grown in Quincy virgin soil in the first, fourth, sixth, and ninth cycles and were assigned a population size of $10^{4} \mathrm{CFU} \mathrm{g^{-1 }}$ root, which is the lower limit of detection. "cultivation" of the soil was not intended to induce TAD, but merely to activate the natural microflora, including the antagonistic microorganisms and resident inoculum of the takeall pathogen. The take-all fungus is naturally present on native and introduced grasses throughout the Pacific Northwest (Sprague 1950). In Quincy TAD soil, populations of rootassociated, Phl-producing Pseudomonas spp. increased during four successive cycles of wheat to a density of $1 \times 10^{6} \mathrm{CFU}$ $\mathrm{g}^{-1}$ root (Fig. 1), and thereafter ranged from $2 \times 10^{5}$ to $7 \times 10^{5}$ $\mathrm{CFU} \mathrm{g}{ }^{-1}$ root. In contrast, Phl-producing Pseudomonas spp. were not detected or were detected at relatively low densities of $2 \times 10^{4} \mathrm{CFU} \mathrm{\textrm {g } ^ { - 1 }}$ on roots of wheat grown in Quincy virgin soil. Successive cultivation of wheat resulted in a significant increase in severity of take-all in the Quincy virgin soil, whereas disease remained negligible in the Quincy TAD soil (Fig. 1). These results demonstrate a strong association between high population densities of indigenous, Phl-producing Pseudomonas spp. and low severity of naturally occurring take-all.

\section{Dose-response relationships.}

Dose-response studies were performed to determine the threshold population density of Phl-producing, fluorescent Pseudomonas spp. required to control take-all of wheat. Threshold density refers to the minimum density at which a significant suppression of take-all of wheat was observed. Phlproducer P. fluorescens Q2-87, isolated in 1987 from Quincy TAD soil, was used as a model strain because $\mathrm{Phl}$ is the main determinant of its activity against the take-all fungus (Vincent et al. 1991; Mazzola et al. 1995). The threshold population

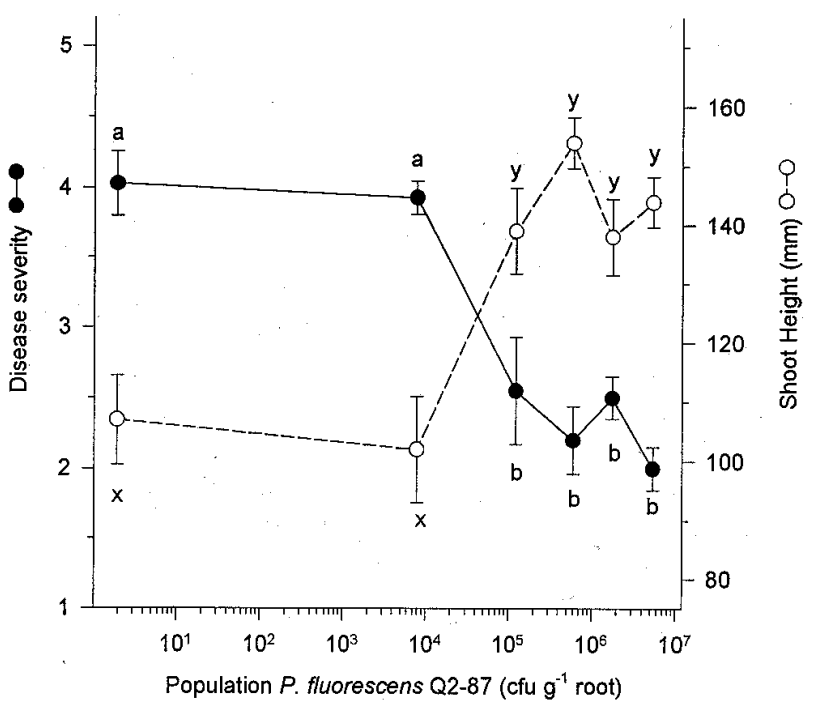

Fig. 2. Relationship between population density of 2,4-diacetylphloroglucinol (Phl)-producing Pseudomonas fluorescens Q2-87 on roots of wheat and, respectively, disease severity and shoot height. Wheat seeds treated with densities of Q2-87 ranging from $10^{2}$ to $10^{7} \mathrm{CFU}$ seed $^{-1}$ were sown in natural Quincy virgin soil amended with $0.5 \%$ (wt/wt) of an oat grain inoculum of the take-all pathogen. Plants were grown for 4 weeks in the greenhouse. Mean values and standard errors are presented. Differences between treatments in shoot height were determined by analysis of variance followed by Tukey's Studentized Range Test $(\alpha=0.05$, MSD $=28.8$ ). Differences in disease severity were analyzed by Wilcoxon rank-sum test $(\alpha=0.05)$. For each parameter, mean values with different letters indicate a statistically significant difference. 
density of Q2-87 required to suppress take-all, as measured by disease severity and shoot height (Fig. 2), was on average 1.2 $\times 10^{5} \mathrm{CFU} \mathrm{g} \mathrm{g}^{-1}$ root $\left( \pm 0.7 \times 10^{5}, 95 \%\right.$ confidence interval $)$. Rhizosphere populations of Q2-87 higher than the threshold density did not significantly improve suppression of take-all. When the experiment was repeated the threshold population density was $4.3 \times 10^{5} \mathrm{CFU} \mathrm{g}^{-1}$ root $\left( \pm 2.3 \times 10^{5}, 95 \%\right.$ confidence interval). Because threshold population densities may differ among Phl-producing Pseudomonas strains, a similar study was performed with another Phl-producing strain, $P$. fluorescens Q8r1-96, isolated in 1996 from the Quincy TAD soil. Based on genotypic analyses, strain Q8r1-96 represented approximately $60 \%$ of the Phl-producing Pseudomonas strains isolated from roots of wheat grown in Quincy TAD soil (J. M. Raaijmakers and D. M. Weller, unpublished data). The threshold population density of Q8r1-96 was $4.6 \times 10^{5} \mathrm{CFU}$ $\mathrm{g}^{-1}$ root $\left( \pm 2.6 \times 10^{5}, 95 \%\right.$ confidence interval $)$. In another experiment, the threshold density of Q8r1-96 was $1.9 \times 10^{5} \mathrm{CFU}$ $\mathrm{g}^{-1}$ root $\left( \pm 1.4 \times 10^{5}, 95 \%\right.$ confidence interval). As was demonstrated for Q2-87, populations of Q8r1-96 higher than the threshold density did not significantly improve suppression of take-all. These results indicate that Phl-producing fluorescent Pseudomonas spp. are present on roots of wheat grown in Quincy TAD soil (Fig. 1) at or above population densities sufficient to control take-all of wheat.

\section{Populations of indigenous, Phl-producing Pseudomonas spp. in the field.}

Brown (1981) stated that "results obtained with young actively-growing seedlings may give interesting and consistent results, but may have little bearing on the TAD phenomenon occurring naturally in the field." Therefore, the frequency of Phl-producing Pseudomonas spp. was determined on roots of mature wheat plants growing in the Pullman and Almota TAD fields in 1996 and 1997, respectively (Table 1). The population density of indigenous Phl-producing fluorescent Pseudomonas spp. on roots of wheat collected from the Pullman TAD field ranged from $1.4 \times 10^{5}$ to $2.0 \times 10^{5} \mathrm{CFU} \mathrm{g} \mathrm{g}^{-1}$ root. In contrast, Phl producers were not detected on roots of mature wheat plants grown in the Pullman take-all-conducive field located directly across the road from the TAD field. On roots of wheat grown in the Almota TAD field, Phl producers were present at a density of $9.3 \times 10^{5} \mathrm{CFU} \mathrm{g}^{-1}$ root. A complemen-

Table 1. Population densities of indigenous 2,4-diacetylphloroglucinol (Phl)-producing fluorescent Pseudomonas spp. on roots of wheat plants collected from the Pullman take-all decline (TAD) and conducive fields and the Almota TAD field

\begin{tabular}{|c|c|c|c|}
\hline Field $^{w}$ & $\begin{array}{c}\text { Date } \\
\text { collected }\end{array}$ & $\begin{array}{l}\text { Population density } \\
\text { of Phl-producing } \\
\text { Pseudomonas spp. } \\
\left(\mathrm{CFU} \mathrm{g}^{-1} \text { root }\right)^{\mathrm{x}}\end{array}$ & $\begin{array}{c}\text { Growth } \\
\text { stage } \\
\text { wheat }{ }^{\mathrm{y}}\end{array}$ \\
\hline Pullman TAD & $7 / 31 / 96$ & $2.0 \times 10^{5}$ & 11 \\
\hline Pullman conducive & $7 / 31 / 96$ & $\mathrm{ND}^{\mathrm{z}}$ & 11 \\
\hline Pullman TAD & $8 / 16 / 96$ & $1.4 \times 10^{5}$ & 11 \\
\hline Pullman conducive & $8 / 16 / 96$ & $\mathrm{ND}^{\mathrm{z}}$ & 11 \\
\hline Almota TAD & $5 / 29 / 97$ & $9.3 \times 10^{5}$ & 9 \\
\hline
\end{tabular}

${ }^{\mathrm{w}}$ At Pullman the winter wheat cv. Madsen was grown; at Almota, the spring wheat $\mathrm{cv}$. Alpowa was grown.

${ }^{x}$ Mean values of six replicates of three plants each are given.

y According to Feekes scale.

${ }^{\mathrm{z}}$ Not detected; lower limit of detection was $10^{4} \mathrm{CFU} \mathrm{g}{ }^{-1}$ root. tary take-all-conducive soil was not available at this site. These results demonstrate that Phl-producing fluorescent Pseudomonas spp. are also present at or above threshold densities on roots of mature wheat plants growing in TAD soils under field conditions.

\section{Elimination of suppressiveness by pasteurization.}

The sensitivity of the TAD factor(s) to pasteurization with moist heat $\left(60^{\circ} \mathrm{C}, 30 \mathrm{~min}\right)$ is one indication of the biological nature of TAD and rules out the involvement of heat-resistant, spore-forming bacteria and probably also actinomycetes (Cook and Baker 1983). Pasteurization of Quincy TAD soil, previously cultivated to wheat for eight successive cycles of 4 weeks each, reduced the population density of Phl-producing Pseudomonas spp. below the threshold level required for significant suppression of take-all and coordinately resulted in a loss of suppressiveness (Fig. 3). The specific suppression that operates in TAD soils can also be eliminated by growing crops, such as oats and alfalfa, that are nonhosts of the take-all pathogen. When oats were grown for two cycles in Quincy TAD soil, previously cultivated to wheat for six successive cycles of 4 weeks each, population densities of Phl-producing Pseudomonas spp. on oat roots dropped below the detection limit of $10^{4} \mathrm{CFU} \mathrm{g}^{-1}$ root in the second cycle (data not shown).

\section{Transfer of suppressiveness to conducive soils.}

Transfer of suppressiveness to conducive soils by introducing small amounts of TAD soil also provides evidence for the biological nature of TAD, and also helps to reveal whether conducive soils can be made suppressive on a practical scale. Mixing Quincy TAD soil, previously cultivated to wheat for eight successive cycles of 4 weeks each, into steamed $\left(95^{\circ} \mathrm{C}\right.$, $2 \mathrm{~h})$ Lind virgin soil in a 1:9 ratio resulted in both the establishment of rhizosphere population densities of Phl-producing fluorescent Pseudomonas spp. in the soil mix above the threshold level and in expression of suppressiveness (Fig. 4). Mixing Quincy virgin soil with steamed Lind virgin soil in a 1:9 ratio provided significantly less control of take-all than that provided with the diluted Quincy TAD soil, but it did provide more protection of wheat than obtained in steamed Lind virgin soil alone (Fig. 4). This latter phenomenon may be attributed to general suppression (Gerlagh 1968), which is related to the total amount of microbiological activity rather than to a specific group of microorganisms. Establishment of rhizosphere populations of $\mathrm{Phl}$ producers above the threshold level and transfer of suppressiveness also was obtained by mixing Quincy TAD soil into raw Pullman conducive soil in a 1:9 ratio (Table 2 ).

\section{Contribution of Phl-producing Pseudomonas spp. to TAD.}

If Phl-producing fluorescent Pseudomonas spp. play a key role in TAD, then introduction of selected strains into takeall-conducive soils at population densities comparable to those occurring in TAD soils should provide control of takeall to a level similar to that obtained in the complementary TAD soil. Introduction of Phl-producing strain Q8r1-96 via seed treatment $\left(10^{4} \mathrm{CFU}\right.$ seed $\left.^{-1}\right)$ into raw Quincy virgin soil and Pullman conducive soil provided suppression of take-all of wheat to a level similar to that obtained in the complementary TAD soils (Table 2). Based on measurements of plant weight and shoot height, the suppression of take-all obtained 
by Q8r1-96 in the conducive soils accounted for on average 85 to $95 \%$ of the suppression in the complementary TAD soils. Strain Q8r1-96 also provided a level of suppression of take-all similar to that obtained by transferring Quincy TAD soil into the Pullman conducive soil in a 1:9 ratio (Table 2). Furthermore, neither Q8r1-96 nor transferred Quincy TAD soil improved suppression of take-all in the Pullman TAD soil (Table 2). These results demonstrated that a single Phlproducing Pseudomonas strain originating from a TAD soil is able to suppress take-all in dissimilar natural conducive soils.

\section{DISCUSSION}

Various lines of evidence provided in this study indicate that fluorescent Pseudomonas spp. producing the antibiotic 2,4-diacetylphloroglucinol ( $\mathrm{Phl})$ play a key role in TAD soils in Washington State (U.S.A.). First, Phl-producing Pseudomonas spp. were present on roots of wheat grown in Quincy, Pullman, and Almota TAD soils at densities at or above the threshold population density required for significant suppression of take-all of wheat, but were below the threshold on roots from conducive soils (Figs. 1 and 2; Table 1). Including the Lind TAD and Moses Lake TAD soils (Raaijmakers et al. 1997), this report now brings to a total of five the number of Washington soils in which take-all decline is associated with Phl-producing fluorescent Pseudomonas spp. Second, successive cultivation of wheat in Quincy TAD and Quincy virgin soils demonstrated a strong association between high populations of indigenous Phl-producing Pseudomonas spp. and low severity of naturally occurring take-all (Fig. 1). Third, the specific suppression that operates in Quincy TAD soil was lost when Phl-producing fluorescent Pseudomonas spp. were eliminated, and conducive soils gained suppressiveness to take-all when Phl-producing Pseudomonas strains were introduced via mixing in small amounts of TAD soil (Figs. 3 and 4). Finally, introduction of a selected Phl-producing Pseudomonas strain into two take-all-conducive soils provided control of take-all to a level similar to that obtained in the complementary TAD soils (Table 2). Given that Phl-producing fluorescent Pseudomonas spp. have been readily isolated from all five Washington TAD soils tested, and from suppressive soils from diverse geographical regions (Keel et al. 1996), we

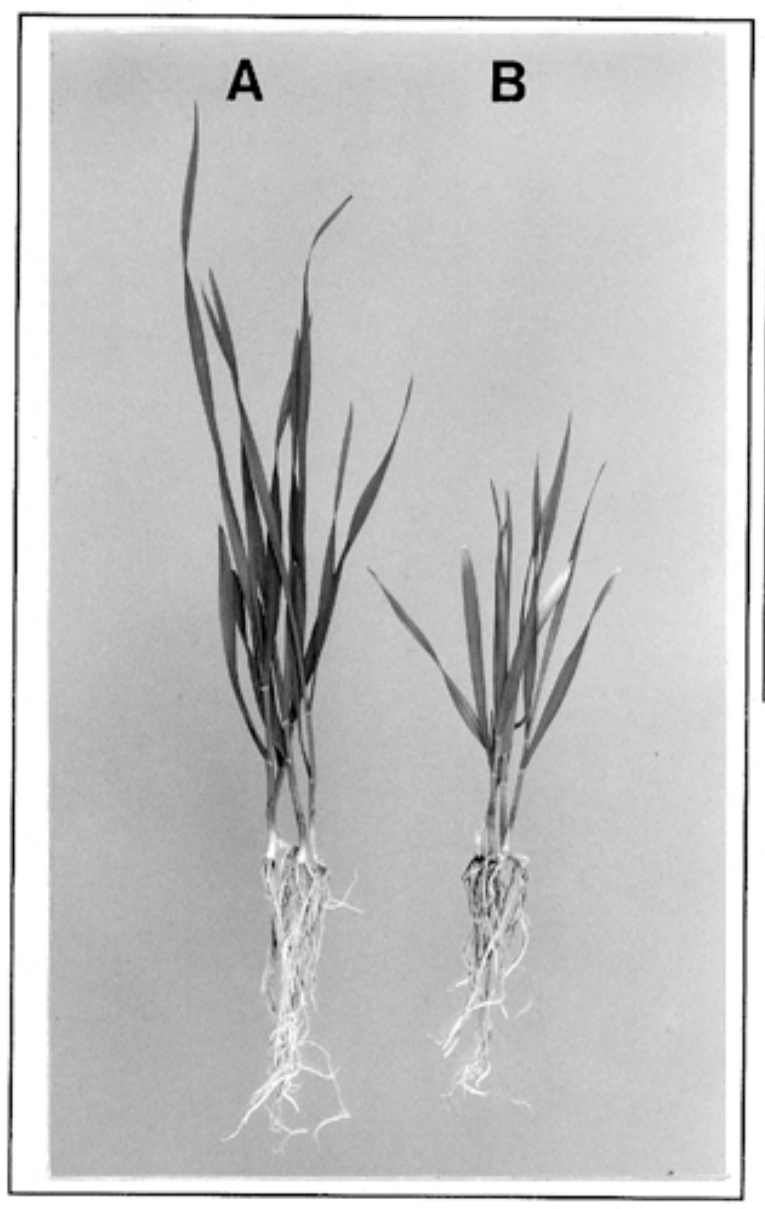

\section{Treatments \\ A: Quincy TAD soil \\ B: Quincy TAD soil pasteurized}

\begin{tabular}{|c|c|}
\hline $\begin{array}{l}\text { Disease Severity } \\
\text { A: } \quad 1.2 \text { a } \\
\text { B: } \quad 4.8 \text { b }\end{array}$ & $\begin{array}{c}\text { Shoot height }(\mathrm{mm}) \\
187 \text { a } \\
141 \text { b }\end{array}$ \\
\hline $\begin{array}{l}\text { Phl-producing Ps } \\
\text { A: } \quad 6 \times 10^{5} \\
\text { B: }\end{array}$ & $\begin{array}{l}\text { eudomonas spp. } \\
{\text { cfu } \mathbf{~ g}^{-1} \text { root }}^{\text {not detected }}\end{array}$ \\
\hline
\end{tabular}

Fig. 3. Effect of pasteurization on take-all suppressiveness of Quincy take-all decline (TAD) soil. The Quincy TAD soil had been previously cultivated to wheat for eight successive cycles of 4 weeks each in the greenhouse. Wheat seeds were sown in natural Quincy TAD soil or in Quincy TAD soil pasteurized with moist heat $\left(60^{\circ} \mathrm{C}, 30 \mathrm{~min}\right)$, both amended with $0.5 \%(\mathrm{wt} / \mathrm{wt})$ of an oat grain inoculum of the take-all pathogen. Plants were grown for 4 weeks under controlled conditions. Mean values of the different parameters are presented. Differences between treatments in shoot height were determined by analysis of variance followed by Tukey's Studentized Range Test $(\alpha=0.05$, MSD $=17.6)$. Differences in disease severity were analyzed by Wilcoxon rank-sum test $(\alpha=0.05)$. For each parameter, mean values with different letters indicate a statistically significant difference. 
now postulate that these specific antibiotic-producing microorganisms play an important role in TAD worldwide. Evidence has been accumulating for decades to suggest that plant protection by naturally occurring microorganisms accounts for certain examples of susceptible plants remaining almost free of infection in spite of ample exposure to virulent inoculum of pathogens (Cook et al. 1995). This study provides more conclusive evidence that antibiotic-producing microorganisms are key components of the specific suppression that operates in natural disease-suppressive soils.

Because the take-all fungus is particularly sensitive to many microorganisms, various other forms of antagonism of the take-all fungus have been described and implicated in take-all decline, including destruction of hyphae by amoebae (Chakraborty and Warcup 1983; Homma et al. 1979), cross protection by $G$. graminis var. graminis or Phialophora graminicola (Deacon 1976; Wong and Southwell 1979), hyphal lysis by a sterile red fungus (Shankar et al. 1994), and antibiosis by actinomycetes (Andrade et al. 1994), Bacillus spp. (Kim et al. 1997), and Pseudomonas spp. (Smiley 1978; Weller and Cook 1983; Charigkapakorn and Sivasithamparam 1987; Sarniguet et al 1992; Ryder and Rovira 1993). However, many of these organisms do not fit one or more of the biological properties of take-all decline reviewed by Cook (1985) and briefly described in this study. For example, the sensitivity of the TAD factor(s) to pasteurization with moist heat $\left(60^{\circ} \mathrm{C}, 30\right.$ min) rules out the involvement of heat-resistant, sporeforming bacteria like Bacillus spp. and probably also actinomycetes (Cook and Baker 1983). Also, phenazine-producing fluorescent Pseudomonas spp. do not seem to be involved in the specific suppression that operates in TAD soils from Washington, because their populations were not enriched on roots of wheat grown in various TAD soils to a level required to control take-all of wheat (Raaijmakers et al. 1997). It should be emphasized, however, that each of these organisms and mechanisms, and others not yet identified, may affect the take-all fungus to one degree or another and provide potential biocontrol agents for the protection of wheat against take-all and other soilborne pathogens.

Plant protection by Phl-producing fluorescent Pseudomonas spp. can be exploited to develop bacterial seed treatments for the control of take-all of wheat that will bypass the years of severe disease prior to the natural onset of take-all decline. The use of wheat seeds treated with Phl-producing Pseudomonas strains is currently being developed as a strategy for take-all control in the irrigated and high-rainfall areas in the Pacific Northwest of the U.S.A. The efficacy of introduced Phl-producing Pseudomonas strains to control take-all in the field will depend on a variety of

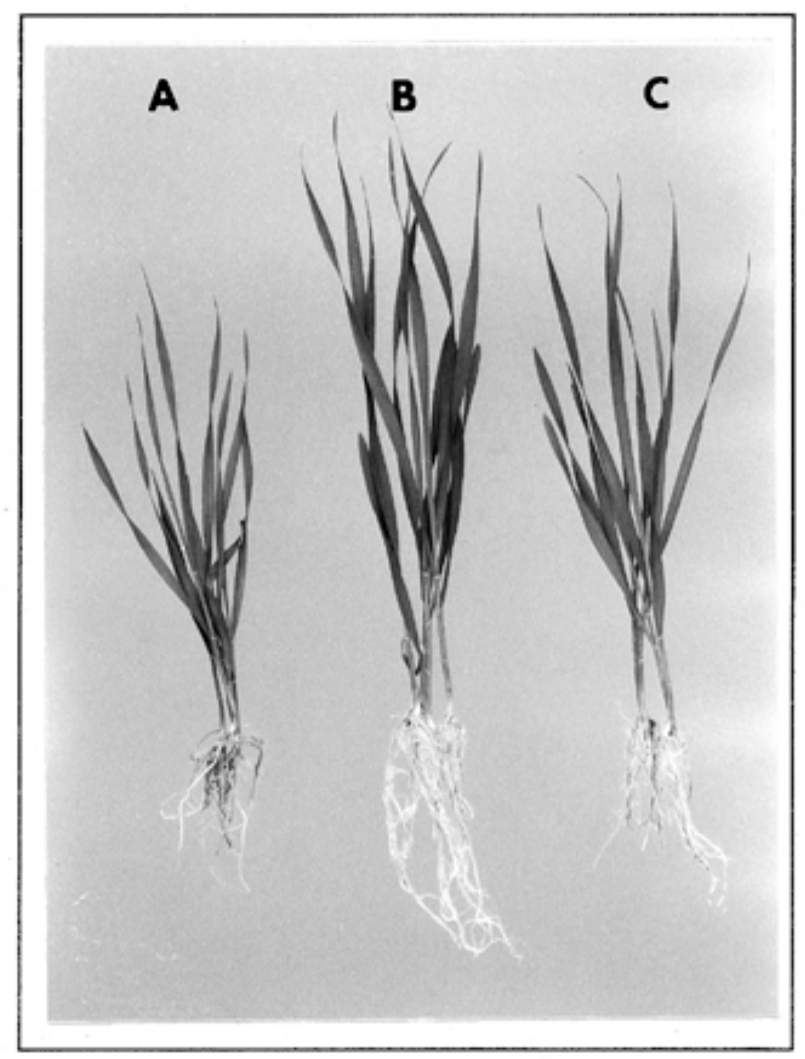

\begin{tabular}{|c|c|}
\hline \multicolumn{2}{|c|}{$\begin{array}{l}\text { Treatments } \\
\text { A: Lind virgin } \\
\text { B: Lind virgin + Quincy TAD soil }(9: 1) \\
\text { C: Lind virgin + Quincy virgin soil }(9: 1)\end{array}$} \\
\hline $\begin{array}{l}\text { Disease severity } \\
\text { A: } \quad 4.2 \text { a } \\
\text { B: } \quad 1.3 \text { c } \\
\text { C: } \quad 3.0 \text { b }\end{array}$ & $\begin{array}{l}\text { Shoot height }(\mathrm{mm}) \\
\begin{aligned} 146 & \text { a } \\
181 & \text { b } \\
165 & \text { ab }\end{aligned}\end{array}$ \\
\hline \multicolumn{2}{|c|}{ 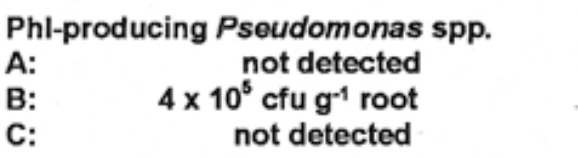 } \\
\hline
\end{tabular}

Fig. 4. Transfer of suppressiveness from Quincy take-all decline (TAD) soil to take-all-conducive Lind virgin soil. The Lind virgin soil was steamed for $2 \mathrm{~h}$ at $95^{\circ} \mathrm{C}$. The Quincy TAD and Quincy virgin soils had been previously cultivated to wheat for eight successive cycles of 4 weeks each in the greenhouse. Wheat seeds were sown in Lind virgin soil, Lind virgin soil mixed with Quincy TAD soil (9:1 ratio, wt/wt), or in Lind virgin soil mixed with Quincy virgin soil $(9: 1 \mathrm{ratio}, \mathrm{wt} / \mathrm{wt})$, all amended with $0.5 \%(\mathrm{wt} / \mathrm{wt})$ of an oat grain inoculum of the take-all pathogen. Plants were grown for 4 weeks under controlled conditions. Mean values of the different parameters are presented. Differences between treatments in shoot height were determined by analysis of variance followed by Tukey's Studentized Range Test $(\alpha=0.05$, MSD $=21.2)$. Differences in disease severity were analyzed by Wilcoxon rank-sum test $(\alpha=0.05)$. For each parameter, mean values with different letters indicate a statistically significant difference. 
epidemiological parameters, including the ability of the introduced organism to establish and maintain threshold population densities on the root system throughout the growing season, and the proportion of the pathogen population that is potentially affected by the antibiotic. Mazzola et al. (1995) showed that various isolates of the take-all fungus can differ in their sensitivity toward Phl. However, isolates collected from the Lind TAD soil were both Phl-sensitive in vitro and controlled on wheat by Phlproducing strain Q2-87. On the basis of experience with chemical pesticides, several key factors will influence the potential for a buildup, if any, of $\mathrm{Phl}$ resistance within the pathogen population. First is the life cycle of the pathogen and the nature of the disease. Resistance develops more rapidly in a sexually reproducing, sporulating pathogen on aerial plant parts than in a slowly expanding, soilborne pathogen like the take-all fungus. Second, the buildup of a resistant pathogen population is favored by a continuously high selection pressure by the chemical compound. For example, a repeated soil drench will allow an uninterrupted exposure to the compound and thereby a prolonged period of selection pressure. Phl-producing Pseudomonas spp. operate in microsites on the root, presumably in the lesions, where only a small fraction of the pathogen population is exposed to the antibiotic during a short period of its life cycle. The third factor in the buildup of resistance is the mode of action of the antibiotic. Despite the fact that $\mathrm{Phl}$ also has antibacterial, antiviral, and anthelminthic properties (Keel et al. 1996), its mode of action is not yet known. Extensive analysis of the variation in Phl-resistance among isolates of the take-all fungus from TAD soils and of the mode of action of this antibiotic will be necessary to better understand this resistance issue. Application of strains that produce multiple antibiotics or a combination of different control strategies may limit the build-up, if any, of resistance within the pathogen population.

Our approach to study disease-suppressive soils may also be useful to identify naturally occurring microorganisms and/ or traits effective against other agriculturally important plant diseases for which no effective management strategies are available. In this context, soils that are naturally suppressive to pathogens such as Fusarium oxysporum, Phytophthora cinnamoni, Pythium spp., Rhizoctonia solani, Streptomyces scabies, and cereal cyst nematode (Cook and Baker 1983; Alabouvette et al. 1993; Larkin et al. 1996) provide an enormous resource for the discovery of new microorganisms and traits. Control of soilborne plant pathogens with plant-associated microorganisms holds an enormous potential as a component of integrated plant disease management and as an approach to move agriculture toward sustainability.

\section{MATERIALS AND METHODS}

\section{Soils.}

Five different soils were obtained from agricultural or virgin fields near the cities of Quincy, Pullman, and Lind in Washington State (U.S.A.). In 1980, the agricultural field at Quincy had been cropped continuously to wheat for 22 years; between 1980 and 1995 other crops besides wheat also were grown. The Quincy soil (Shano silt loam) (Raaijmakers et al. 1997) is one of the best-studied take-all decline soils in the U.S.A. and the transferability of its suppressiveness to conducive soils has been described in both greenhouse and field studies (Shipton et al. 1973). A complementary take-allconducive soil, designated Quincy virgin (Shano sandy loam), was collected from a site covered by native vegetation within $2 \mathrm{~km}$ of the Quincy TAD field (Raaijmakers et al. 1997). Both soils were collected in March 1995 from the upper $30 \mathrm{~cm}$ of the soil profile, air dried for 1 week, and passed through a 0.5 cm-mesh screen prior to use. In 1996, the Pullman TAD field (Thatuna silt loam; located on the USDA-ARS Soil Conservation Research Farm near Pullman, WA) had been cropped no-till for 15 consecutive years with 13 years of wheat or barley and 1 year each of chemical fallow (1987) and peas (1994), and had recently entered the TAD state (R. J. Cook,

Table 2. Effect of 2,4-diacetylphloroglucinol (Phl)-producing Pseudomonas fluorescens Q8r1-96 and of transferred Quincy TAD soil on the severity of take-all in natural soils

\begin{tabular}{|c|c|c|c|c|}
\hline Treatments $^{v}$ & Phl producers $\left(\mathrm{CFU} \mathrm{g}^{-1} \text { root }\right)^{\mathrm{w}}$ & Disease severity $^{\mathbf{w}, \mathbf{x}}$ & Plant weight $(\mathbf{m g})^{\mathrm{w}}$ & Shoot height $(\mathbf{m m})^{\mathrm{w}}$ \\
\hline \multicolumn{5}{|l|}{ Experiment 1} \\
\hline Quincy virgin & Not detected ${ }^{y}$ & $4.2 \mathrm{a}$ & $180 \mathrm{a}$ & 106 a \\
\hline Quincy virgin + Q8r1-96 & $4.6 \times 10^{6} \mathrm{a}$ & $3.1 \mathrm{~b}$ & $262 \mathrm{~b}$ & $133 \mathrm{~b}$ \\
\hline Quincy TAD & $3.7 \times 10^{5} \mathrm{~b}$ & $2.5 \mathrm{~b}$ & $281 \mathrm{~b}$ & $139 \mathrm{~b}$ \\
\hline \multicolumn{5}{|l|}{ Experiment 2} \\
\hline Pullman Cond & Not detected & $3.8 \mathrm{a}$ & $212 \mathrm{a}$ & $142 \mathrm{a}$ \\
\hline Pullman Cond + Quincy TAD $(9: 1)^{\mathrm{z}}$ & $4.5 \times 10^{5} \mathrm{a}$ & $2.1 \mathrm{~b}$ & $335 \mathrm{~b}$ & $181 \mathrm{~b}$ \\
\hline Pullman Cond + Q8r1-96 & $4.5 \times 10^{7} \mathrm{c}$ & $2.5 \mathrm{~b}$ & $288 \mathrm{~b}$ & $172 \mathrm{~b}$ \\
\hline Pullman TAD & $1.3 \times 10^{6} \mathrm{~b}$ & $1.9 \mathrm{~b}$ & $336 \mathrm{~b}$ & $184 \mathrm{~b}$ \\
\hline Pullman TAD + Quincy TAD $(9: 1)^{\mathrm{z}}$ & $3.5 \times 10^{5} \mathrm{a}$ & $2.3 \mathrm{~b}$ & $286 \mathrm{~b}$ & $177 \mathrm{~b}$ \\
\hline Pullman TAD + Q8r1-96 & $3.4 \times 10^{7} \mathrm{c}$ & $2.3 \mathrm{~b}$ & $306 \mathrm{~b}$ & $178 \mathrm{~b}$ \\
\hline \multirow{3}{*}{\multicolumn{5}{|c|}{$\begin{array}{l}\mathrm{v} \text { The Quincy virgin and Pullman Cond soils are both conducive to take-all of wheat, whereas the complementary TAD soils are suppressive to take-all. } \\
\text { Quincy virgin and Quincy TAD soils had previously been cultivated to wheat for six successive cycles of } 4 \text { weeks each to activate the microflora. The } \\
\text { Pullman Cond and the Pullman TAD soil were obtained directly from fields grown to wheat. All soils were amended with } 0.5 \% \text { (wt/wt) of an oat grain } \\
\text { inoculum of the take-all pathogen. Wheat seeds treated with Q8r1-96 received a dose of } 10^{4} \mathrm{CFU} \mathrm{seed}{ }^{-1} \text {. }\end{array}$}} \\
\hline & & & & \\
\hline & & & & \\
\hline \multirow{4}{*}{\multicolumn{5}{|c|}{$\begin{array}{l}\text { w Population sizes of introduced strain Q8r1-96 or of naturally occurring, Phl-producing fluorescent Pseudomonas spp.; disease severity, plant fresh } \\
\text { weight, and shoot height were determined after } 4 \text { weeks of plant growth. Mean values of six replicates of two plants each are presented. Differences } \\
\text { between treatments in population densities of Phl-producing Pseudomonas spp., plant fresh weight, and shoot height were determined by analysis of } \\
\text { variance followed by Tukey's Studentized Range Test. Differences in disease severity were analyzed by Wilcoxon rank-sum test. For each experiment } \\
\text { and for each parameter, mean values with different letters indicate a statistically significant difference }(\alpha=0.05) \text {. }\end{array}$}} \\
\hline & & & & \\
\hline & & & & \\
\hline & & & & \\
\hline \multicolumn{5}{|c|}{ Severity of take-all was rated on a 0 to 8 scale $(0=$ no disease, and $8=$ dead plant). } \\
\hline \multicolumn{5}{|c|}{${ }^{y}$ Below lower limit of detection of $10^{4} \mathrm{CFU} \mathrm{g}^{-1}$ root. } \\
\hline & & & & \\
\hline
\end{tabular}


personal communication). In a field (Thatuna silt loam) located directly across the road from the Pullman TAD field, hereafter referred to as Pullman conducive, wheat had been grown only once every 3 to 4 years during the past 20 years and the soil was conducive to take-all. The Pullman soils were collected in July 1996 in the same way as described for the Quincy soils. The Lind virgin soil (Ritzville silt loam) (Raaijmakers et al. 1997) was collected from a site covered by native vegetation in March 1995, and is conducive to take-all of wheat.

\section{Successive cycling of wheat.}

Twelve wheat seeds (cv. Penewawa) were sown in square PVC pots ( $8 \mathrm{~cm}$ high, $7.5 \mathrm{~cm}$ wide) containing $200 \mathrm{~g}$ of sieved natural soil and $50 \mathrm{ml}$ of water supplemented with metalaxyl (Ciba-Geigy, Greensboro, NC) at $2.5 \mathrm{mg} \mathrm{ml}^{-1}$ active ingredient to control Pythium root rot. Pseudomonads are not affected by this fungicide (Weller and Cook 1983). A 1-cm layer of soil was spread on top of the seeds. Plants were grown in a controlled-environment chamber at $16^{\circ} \mathrm{C}$ with a 12 -h photoperiod. Pots received $50 \mathrm{ml}$ of dilute (2:3, vol/vol) Hoaglund's solution (macro-elements only) twice a week. After 3 weeks of growth, the shoots of the plants were excised at the soil surface, and the soil and associated root system were decanted into a plastic bag and shaken vigorously to aerate and mix. This "cultivated" soil was stored for 1 week at $15^{\circ} \mathrm{C}$, returned to the same pot, and then replanted with 12 wheat seeds. This process of plant growth and harvesting was repeated for a total of nine cycles (36 weeks). At the end of each cycle, six randomly selected plants were harvested from each replicate. Root samples were prepared from three plants to determine the population size of naturally occurring, Phl-producing fluorescent Pseudomonas spp. Disease severity caused by the indigenous take-all fungus was determined on three plants per replicate, and was rated on a 0 to 8 scale $(0=$ no disease, and 8 = dead plant) (Thomashow and Weller 1988). For each soil, six replicates were used.

\section{Isolation of root-associated Pseudomonas spp.}

Three randomly selected wheat plants were harvested from each replicate and loosely adhering soil was removed from the roots by gently shaking them. One gram of roots and associated rhizosphere soil was suspended in $5.0 \mathrm{ml}$ of sterile water and shaken vigorously for $1 \mathrm{~min}$ on a Vortex mixer. The samples were subsequently sonicated in a ultrasonic cleaner for 1 min, and then serial dilutions of the root wash were plated onto King's medium B agar (King et al. 1954) supplemented with cycloheximide $\left(100 \mu \mathrm{g} \mathrm{ml}^{-1}\right)$, chloramphenicol $(13 \mu \mathrm{g}$ $\left.\mathrm{ml}^{-1}\right)$, and ampicillin $\left(40 \mu \mathrm{g} \mathrm{m}^{-1}\right)\left(\mathrm{KMB}^{+}\right)$(Simon and Ridge 1974). Plates were incubated at $25^{\circ} \mathrm{C}$ and colonies were enumerated after $48 \mathrm{~h}$. Colonies of fluorescent Pseudomonas spp. were differentiated from nonfluorescent colonies under UV light (wavelength $366 \mathrm{~nm}$ ). The number of fluorescent Pseudomonas spp. that harbor the genes for Phl was determined by colony hybridization with a Phl-specific probe followed by polymerase chain reaction (PCR) analysis with Phl-specific primers.

\section{Colony hybridization.}

Transfer of bacterial colonies to Hybond- $\mathrm{N}^{+}$nylon membranes (Amersham, Little Chalfont, UK) was performed by standard methods (Sambrook et al. 1989). After air drying, the membranes were baked for $1 \mathrm{~h}$ at $80^{\circ} \mathrm{C}$ in a vacuum oven. To remove bacterial cell debris, the membranes were washed for $1.5 \mathrm{~h}$ at $42^{\circ} \mathrm{C}$ in a solution containing $2 \times \operatorname{SSPE}(20 \mathrm{mM}$ $\mathrm{NaH}_{2} \mathrm{PO}_{4}$ [pH 7.4], $0.36 \mathrm{M} \mathrm{NaCl}$, and $2 \mathrm{mM}$ EDTA), $0.1 \%$ sodium dodecyl sulfate (SDS), and pronase $\left(100 \mu \mathrm{g} \mathrm{ml}^{-1}\right)$, and washed again for $1 \mathrm{~h}$ at $56^{\circ} \mathrm{C}$ in $2 \times \mathrm{SSPE}$ and $0.1 \%$ SDS. Hybridizations were performed under high stringency conditions by standard methods (Sambrook et al. 1989). The Phl-probe consisted of the 745-bp DNA fragment amplified by PCR from Phl-producing strain Pseudomonas fluorescens Q2-87 (Raaijmakers et al. 1997) and was generated by random primed labeling with the nonradioactive DIG system (Boehringer Mannheim, Mannheim, Germany). The hybridized probe was immunodetected with anti-digoxigenin-AP-Fab fragments and Phl-positive colonies were visualized with the colorometric substrates nitroblue tetrazolium salt and 5bromo-4-chloro-3-indolylphosphate, according to protocols provided by the supplier. The lower limit of detection of indigenous Phl-producing Pseudomonas spp. was $10^{4} \mathrm{CFU} \mathrm{g}^{-1}$ root fresh weight (Raaijmakers et al. 1997). Positive colonies of fluorescent Pseudomonas strains were isolated and purified on KMB agar plates. PCR analysis of the isolated colonies was performed as a quality check of the colony hybridization (Raaijmakers et al. 1997).

\section{PCR analysis.}

The oligonucleotide primers $\mathrm{Phl} 2 \mathrm{a}$ and $\mathrm{Phl} 2 \mathrm{~b}$ (Raaijmakers et al. 1997) were developed from sequences within PhlD, one of the six genes in the biosynthetic locus for 2,4-diacetylphloroglucinol (Phl) of P. fluorescens Q2-87 (GenBank accession no. U41818). $P h l \mathrm{D}$ predicts a protein of 349 amino acids that is homologous to chalcone and stilbene synthases from plants (Bangera et al. 1996). Primers Phl2a and Phl2b were synthesized by Operon Technologies (Alameda, CA) and yield a 745-bp fragment (Raaijmakers et al. 1997). DNA isolation by cell lysis and PCR amplification was carried out according to the methods described by Raaijmakers et al. (1997).

\section{Isolation of indigenous Phl-producing Pseudomonas spp. from field-grown wheat.}

The frequency of Phl-producing Pseudomonas spp. was also determined on roots of mature wheat plants growing in the Pullman TAD and conducive fields in 1996 and from the Almota TAD field in 1997. The Almota TAD field (commercial wheat farm near Pullman, WA) had been cropped no-till for at least 5 consecutive years with wheat and had recently entered the TAD state (R. J. Cook, personal communication). Characteristics of the Pullman TAD and conducive soils are described above. From the TAD and conducive fields, wheat plants (cv. Madsen) were collected at random from six different sites within each field. Root samples were prepared from three plants per site and processed as described above. Populations of indigenous Phl-producing Pseudomonas spp. were determined by colony hybridization followed by PCR as described above.

\section{Dose-response studies.}

Wheat seeds (cv. Penewawa) were coated with $1 \%$ methyl cellulose, or with a suspension of spontaneous rifampinresistant derivatives of $P$. fluorescens Q2-87 or Q8r1-96 in 1\% 
methyl cellulose (Weller et al. 1985). The coated seeds were air dried for $5 \mathrm{~h}$ in a laminar flow cabinet. Final densities of Q2-87 or Q8r1-96 were approximately $10^{1}, 10^{2}, 10^{3}, 10^{4}, 10^{5}$, $10^{6}$, or $10^{7} \mathrm{CFU}$ per seed, as determined by dilution plating on KMB supplemented with rifampin $\left(100 \mu \mathrm{g} \mathrm{ml}{ }^{-1}\right)$. Treated seeds were sown in raw Quincy virgin soil amended with $0.5 \%(\mathrm{wt} / \mathrm{wt})$ of an oat grain inoculum of the take-all pathogen (Weller et al. 1985). Plants were grown for 4 weeks under controlled conditions $\left(16^{\circ} \mathrm{C}, 12\right.$-h photoperiod). Each treatment had six replications and consisted of nine plants per replicate. From each replicate, six randomly selected plants were harvested, and disease severity, shoot height, and population size of Q2-87 or Q8r1-96 were determined on two plants each. Severity of take-all was rated on a 0 to 8 scale in which $0=$ no disease and $8=$ dead plant (Thomashow and Weller 1988). Shoot height was determined by measuring the length of the seedling from the point of seed attachment to the tip of the longest leaf. Population densities of Q2-87 and Q8r1-96 were determined by dilution plating root washes onto agar medium supplemented with $100 \mu \mathrm{g} \mathrm{ml}^{-1}$ rifampin.

\section{Elimination and transfer of suppressiveness.}

The specific suppression that operates in TAD soils can be eliminated by pasteurization with moist heat (Shipton et al. 1973). The Quincy TAD soil, previously cultivated to wheat for eight successive cycles of 4 weeks each, was treated for 30 min with a steam-air mixture to give a pasteurization temperature of $60^{\circ} \mathrm{C}$. This treatment was reported to be sufficient to eliminate the suppressive factor(s) (Shipton et al. 1973). Transfer of suppressiveness to conducive soils was studied by mixing Quincy TAD or Quincy virgin soils into either steamed $\left(95^{\circ} \mathrm{C}, 2 \mathrm{~h}\right)$ Lind virgin soil or raw Pullman conducive soil in a $1: 9$ ratio. After mixing the soils, $0.5 \%(\mathrm{wt} / \mathrm{wt})$ of an oat grain inoculum (particle size 0.25 to $0.5 \mathrm{~mm}$ ) of the take-all pathogen was introduced into soil, and plants were grown for 4 weeks under controlled conditions $\left(16^{\circ} \mathrm{C}, 12\right.$-h photoperiod). Each treatment had six replications and consisted of nine plants per replicate. From each replicate, six randomly selected plants were harvested, and disease severity, shoot height, and population size of indigenous, Phl-producing fluorescent Pseudomonas spp. were determined on two plants each as described above. Plant weight was determined on the basis of fresh weight of the whole wheat seedling.

\section{Statistical analysis.}

Differences between treatments in population densities, shoot height, and plant fresh weight were determined by analysis of variance followed by Tukey's Studentized Range Test (SAS Inc., Cary, NC). Differences in disease severity were analyzed by Wilcoxon rank-sum test $(\alpha=0.05)$. Each experiment was performed at least twice. Representative results of one experiment are shown.

\section{ACKNOWLEDGMENTS}

We are grateful to C. Alabouvette, R. J. Cook, J. W. Deacon, L. L. Kinkel, R. P. Larkin, M. Mazzola, and B. Schippers for their critical reviews and valuable suggestions, and to Oi Tak Wong for his excellent technical assistance. We are especially grateful to R. J. Cook for providing plants and soil from the TAD fields at Pullman and Almota, WA. This research was supported by NRI-CGP grant 94-37107-0439.

\section{LITERATURE CITED}

Alabouvette, C., Lemanceau, P., and Steinberg, C. 1993. Recent advances in the biological control of Fusarium wilts. Pestic. Sci. 37:365373.

Andrade, O. A., Mathre, D. E., and Sands, D. C. 1994. Natural suppression of take-all disease of wheat in Montana soils. Plant Soil 164:918.

Asher, M. J. C., and Shipton, P. J. 1981. Biology and Control of Takeall. Academic Press, New York.

Bangera, M. G., Weller, D. M., and Thomashow, L. S. 1996. Genetic analysis of the 2,4-diacetylphloroglucinol biosynthetic locus from Pseudomonas fluorescens Q2-87. Pages 383-386 in: Advances in Molecular Genetics of Plant-Microbe Interactions, vol. 3. M. J. Daniels, J. A. Downie, and A. E. Osbourn, eds. Kluwer Academic Publishers, Dordrecht, The Netherlands.

Brown, M. E. 1981. Microbiology of roots infected with the take-all fungus (Gaeumannomyces graminis var. tritici) in phased sequence of winter wheat. Soil Biol. Biochem. 13:285-291.

Chakraborty, S., and Warcup, J. H. 1983. Soil amoebae and saprophytic survival of Gaeumannomyces graminis tritici in a suppressive pasture soil. Soil Biol. Biochem. 15:181-185.

Charigkapakorn, N., and Sivasithamparam, K. 1987. Changes in the composition and population of fluorescent pseudomonads on wheat roots inoculated with successive generations of root-piece inoculum of the take-all fungus. Phytopathology 77:1002-1007.

Cook, R. J. 1985. Biological control of plant pathogens, with special reference to the take-all fungus in suppressive soils. Pages 179-198 in: Taiwan Agric. Res. Inst. Plant Prot. Bull. 27.

Cook, R. J., and Baker, K. F. 1983. The Nature and Practice of Biological Control of Plant Pathogens. American Phytopathological Society, St. Paul, MN.

Cook, R. J., and Rovira, A. D. 1976. The role of bacteria in the biological control of Gaeumannomyces graminis by suppressive soils. Soil Biol. Biochem. 8:269-273.

Cook, R. J., Thomashow, L. S., Weller, D. M., Fujimoto, D., Mazzola, M., Bangera, G., and Kim, D.-S. 1995. Molecular mechanisms of defense by rhizobacteria against root disease. Proc. Natl. Acad. Sci. USA 92:4197-4201.

Deacon, J. W. 1976. Biological control of the take-all fungus, Gaeumannomyces graminis by Phialophora radicicola and similar fungi. Soil Biol. Biochem. 8:275-283.

Fellows, H., and Ficke, C. H. 1934. Report on wheat take-all in cereal and forage crop disease investigations. Rep. Kans. Exp. Stn. 7:19321934.

Foex, E. 1935. Quelques observations sur les maladies du pied des cereales. C. R. Hebd. Acad. Agric. Fr. 21:501-505.

Gerlagh, M. 1968. Introduction of Ophiobolus graminis into new polders and its decline. Neth. J. Plant Pathol. 74(suppl. 2):1-97.

Glynne, M. D. 1935. Incidence of take-all on wheat and barley on experimental plots at Woburn. Ann. Appl. Biol. 22:225-235.

Gutteridge R.J., Hornby, D., Hollins, T. W., and Prew, R. D. 1993. Takeall in autumn-sown wheat, barley, triticale and rye grown with high and low inputs. Plant Pathol. 42:425-431.

Homma, Y., Sitton, J. W., Cook, R. J., and Old, K. M. 1979. Perforation and destruction of pigmented hyphae of Gaeumannomyces graminis by vampyrellid amoebae from Pacific Northwest wheat field soils. Phytopathology 69:1118-1122.

Hornby, D. 1983. Suppressive soils. Annu. Rev. Phytopathol. 21:65-85.

Keel, C., Schnider, U., Maurhofer, M., Voisard, C., Laville, J., Burger, U., Wirthner, P., Haas, D., and Défago, G. 1992. Suppression of root diseases by Pseudomonas fluorescens CHA0: Importance of the bacterial secondary metabolite 2,4-diacetylphloroglucinol. Mol. PlantMicrobe Interact. 5:4-13.

Keel, C., Weller, D., Natsch, A., Défago, G., Cook, R. J., and Thomashow, L. S. 1996. Conservation of the 2,4-diacetylphloroglucinol biosynthesis locus among fluorescent Pseudomonas strains from diverse geographic locations. Appl. Environ. Microbiol. 62:552-563.

Kim, D.-S., Cook, R. J., and Weller, D. M. 1997. Bacillus sp. L324-92 for biological control of three root diseases of wheat grown with reduced tillage. Phytopathology 87:551-558.

King, E. O., Ward, M. K., and Raney, D. E. 1954. Two simple media for the demonstration of pyocyanin and fluorescein. J. Lab. Clin. Med. 44:301-307. 
Larkin, R. P., Hopkins, D. L., and Martin, F. N. 1996. Suppression of Fusarium wilt of watermelon by nonpathogenic Fusarium oxysporum and other microorganisms recovered from a disease-suppressive soil. Phytopathology 86:812-819.

Linde-Laursen, I., Jensen, H.P., and Jorgensen J.H. 1973. Resistance of Triticale, Aegilops, and Haynaldia species to the take-all fungus, Gaeumannomyces graminis. Z. Pflanzenzuecht. 70:200-213.

Mazzola, M., Fujimoto, D. K., Thomashow, L. S., and Cook, R. J. 1995. Variation in sensitivity of Gaeumannomyces graminis to antibiotics produced by fluorescent Pseudomonas spp. and effect on biological control of take-all of wheat. Appl. Environ. Microbiol. 61:2554-2559.

Raaijmakers, J. M., Weller, D. M., and Thomashow, L. S. 1997. Frequency of antibiotic producing Pseudomonas spp. in natural environments. Appl. Environ. Microbiol. 63:881-887.

Rovira, A. D., and Wildermuth, G. B. 1981. Pages 385-414 in: Biology and Control of Take-all. M. J. C. Asher and P. J. Shipton, eds. Academic Press, New York.

Ryder, M. H., and Rovira, A. D. 1993. Biological control of take-all of glasshouse-grown wheat using strains of Pseudomonas corrugata isolated from wheat field soil. Soil Biol. Biochem. 25:311-320.

Sambrook, J., Fritsch, E. F., and Maniatis, T. A. 1989. Molecular Cloning: A Laboratory Manual. 2nd ed. Cold Spring Harbor Laboratory, Cold Spring Harbor, NY.

Sarniguet, A., Lucas, P., and Lucas, M. 1992. Relationships between take-all, soil conduciveness to the disease, populations of fluorescent pseudomonads and nitrogen fertilizers. Plant Soil 145:17-27.

Shankar, M., Kurtboke, D. I., Gillespie-Sasse, L. M. J., Rowland, C. Y., and Sivasithamparam, K. 1994. Possible role of competition for thiamine, production of inhibitory compounds, and hyphal interactions in suppression of the take-all fungus by a sterile red fungus. Can. J. Microbiol. 40:478-483.

Shipton, P. J. 1975. Take-all decline during cereal monoculture. Pages 137-144 in: Biology and Control of Soil-Borne Plant Pathogens. G. W. Bruehl, ed. American Phytopathological Society, St. Paul, MN.
Shipton, P. J., Cook, R. J., and Sitton, J. W. 1973. Occurrence and transfer of a biological factor in soil that suppresses take-all of wheat in eastern Washington. Phytopathology 63:511-517.

Simon, A., and Ridge, E. H. 1974. The use of ampicillin in a simplified selective medium for the isolation of fluorescent pseudomonads. J. Appl. Bacteriol. 37:459-460.

Slope, D. B., and Cox, J. 1964. Continuous wheat growing and the decline of take-all. Rep. Rothamsted Exp. Stn. 1963.

Smiley, R. W. 1978. Colonization of wheat roots by Gaeumannomyces graminis inhibited by specific soils, microorganisms and ammoniumnitrogen. Soil Biol. Biochem. 10:175-179.

Sprague, R. 1950. Diseases of Cereals and Grasses in North America (Fungi, Except Smuts and Rusts). Ronald Press, New York.

Thomashow, L.S. and Weller, D. M. 1988. Role of a phenazine antibiotic from Pseudomonas fluorescens in biological control of Gaeumannomyces graminis var. tritici. J. Bacteriol. 170:3499-3508.

Vincent, M. N., Harrison, L. A., Brackin, J. M., Kovacevich, P. A., Mukerji, P., Weller, D. M., and Pierson, E. A. 1991. Genetic analysis of the antifungal activity of a soilborne Pseudomonas aureofaciens strain. Appl. Environ. Microbiol. 57:2928-2934.

Weller, D. M., and Cook, R. J. 1983. Suppression of take-all of wheat by seed treatments with fluorescent pseudomonads. Phytopathology 73: 463-469.

Weller, D. M., Howie, W. J., and Cook, R. J. 1988. Relationship between in vitro inhibition of Gaeumannomyces graminis var. tritici and suppression of take-all of wheat by fluorescent pseudomonads. Phytopathology 78:1094-1100.

Weller, D. M., Zhang, B.-X., and Cook, R. J. 1985. Application of a rapid screening test for selection of bacteria suppressive to take-all of wheat. Plant Dis. 69:710-713.

Wong, P. T. W., and Southwell, R. J. 1979. Biological control of take-all in the field using Gaeumannomyces graminis var. graminis and related fungi. Pages 597-602 in: Soil-borne Plant Pathogens, B. Schippers and W. Gams, eds., Academic Press, London. 